\title{
Changes in intestinal absorption of nutrients and brush border glycoproteins after total parenteral nutrition in rats
}

\author{
S Miura, S Tanaka, M Yoshioka, H Serizawa, H Tashiro, H Shiozaki, H Imaeda, M Tsuchiya
}

\begin{abstract}
The effect of total parenteral nutrition on nutrients absorption and glycoprotein changes of brush border membrane was examined in rat small intestine. In total parenteral nutrition rats, a marked decrease in activity of brush border enzymes was observed mainly in the proximal and middle segments of the intestine. Galactose perfusion of jejunal segment showed that hexose absorption was significantly inhibited, while intestinal absorption of glycine or dipeptide, glycylglycine was not significantly affected by total parenteral nutrition treatment. When brush border membrane glycoprotein profile was examined by $\left[{ }^{3} \mathrm{H}\right]$-glucosamine or $\left[{ }^{3} \mathbf{H}\right]-f u c o s e$ incorporation into jejunal loops, significant changes were observed in the glycoprotein pattern of brush border membrane especially in the high molecular weight range over $120 \mathrm{kDa}$ after total parenteral nutrition treatment, suggesting strong dependency of glycoprotein synthesis on luminal substances. Molecular weight of sucrase isomaltase in brush border membrane detected by specific antibody showed no significant difference, however, in total parenteral nutrition and control rats. Also, molecular weight of specific sodium glucose cotransporter of intestinal brush border membrane detected by selective photoaffinity labelling was not altered in total parenteral nutrition rats. It may be that prolonged absence of oral food intake may produce significant biochemical changes in brush border membrane glycoprotein and absorptive capacity of small intestine, but these changes were not observed in all brush border membrane glycoproteins.
\end{abstract}

Division of

Gastroenterology,

Department of Internal

Medicine, School of

Medicine, Keio

University, Tokyo, Japan

S Miura

S Tanaka

M Yoshioka

H Serizawa

H Tashiro

H Shiozaki

H Imaeda

M Tsuchiya

Correspondence to:

Dr $S$ Miura, Division of Gastroenterology,

Department of Internal Medicine, School of

Medicine, Keio University, 35

Shinanomachi, Shinjuku-ku,

Tokyo 160, Japan.

Address for reprints:

$\operatorname{Dr} M$ Tsuchiya, at above address.

Accepted for publication 2 July 1991
Ingestion of food and the presence of nutrients in the intestine appear to play an essential role in the maintenance of normal small bowel structure and function. It is known, for example, that when exogenous luminal nutrition is completely excluded from the intestine of animals, mucosal hypoplasia develops in the small intestinal mucosa. ${ }^{12}$ Total parenteral nutrition, unlike starvation, is able to examine the effect of exclusion of luminal feeding without alterating total body energy and nitrogen balance. . $^{3-5}$

Brush border membrane of small intestinal absorptive cells contains various hydrolases and carrier molecules and is known to be the most biologically active site where assimilation of dietary nutrients takes place. ${ }^{6}$ Although total parenteral nutrition affects the small bowel morphology and function, there is relative paucity of data concerning how total parenteral nutrition produces changes in biochemical and biophysical properties in the brush border membrane. ${ }^{7-11}$ The aim of this study is therefore to compare the absorptive function of different kinds of nutrients in the rat small intestine maintained with total parenteral nutrition and also to elucidate whether any biochemical changes occur in the glycoproteins and glycoenzymes of brush border membrane of these animals.

\section{Methods}

ANIMALS AND METHOD FOR TOTAL PARENTERAL NUTRITION

Male Wistar rats initially weighing $200 \mathrm{~g}$ were used for these experiments. The technique used for total parenteral nutrition was a modification of the one described by Steiger, Vars, and Dudrick. ${ }^{12}$ Briefly, an indwelling silastic catheter was passed through the jugular vein into the right atrium. The intravenous feeding line was attached to the swivel and to the rat by a harness. Intravenous nutrients were infused throughout the 24 hour period with an infusion pump (Truth type B-II, Tokyo) at $30 \mathrm{ml} /$ day in the beginning and gradually increased to an infusion rate of 50 $\mathrm{ml} /$ day by the beginning of the fourth postoperative day. Nutrients solution contains: glucose $206 \mathrm{~g} / \mathrm{l}$, amino acids $33 \mathrm{~g} / \mathrm{l}$, electrolytes ( $\mathrm{Na}, \mathrm{K}$, $\mathrm{Cl}, \mathrm{Mg}, \mathrm{Ca}, \mathrm{P}$ ), vitamins, trace elements and essential fatty acids. Control rats were sham operated and fitted with harness assemblies similar to those fastened to the backs of parenterally fed rats. Control rats were orally fed with the same amount of nutrient solution per day served ad libitum. The metabolic tolerance to this regimen was monitored by the general appearance of the animal, by blood test and by urine testing to exclude glycosuria, proteinuria, and aciduria.

TISSUE PREPARATION AND ENZYME ASSAY

Fourteen days after initiation of total parenteral nutrition, intestinal absorption and glycoprotein synthesis were determined in parenterally and enterally fed rats. A $10 \mathrm{~cm}$ jejunal segment distal to the ligament of Treitz, a $10 \mathrm{~cm}$ middle small intestinal segment and a $10 \mathrm{~cm}$ ileal segment ending $5 \mathrm{~cm}$ from the caecum were removed. The mucosa was scraped from each segment and brush border membrane was prepared by the method of Kessler et al. ${ }^{13}$ Aminopeptidase N activity was measured with $2 \mathrm{mM}$ leu- $\beta$-naphthylamide as substrate using previously described procedures. ${ }^{14}$ Alkaline phosphatase was assayed as described by Fujita et al. ${ }^{15}$ Activities 
of intestinal disaccharidases were monitored according to the method of Dahlqvist. ${ }^{16}$ Protein was measured by the method of Lowry et al. ${ }^{17}$

\section{IN VIVO PERFUSION STUDY}

In vivo perfusion of galactose, glycine, and glycylglycine (gly-gly) were performed using a steady-state perfusion technique. ${ }^{18}$ Galactose (16 $\mathrm{mM}$ or $32 \mathrm{mM})$, glycine $(20 \mathrm{mM}$ or $50 \mathrm{mM})$, glygly (10 mM) (Sigma, MO, USA) were prepared in isotonic saline (the osmolarity of all solutions was adjusted to $350 \mathrm{mosmol} / \mathrm{kg}$ by sodium chloride with osmometer), and the $\mathrm{pH}$ was adjusted to $7 \cdot 4$ and $\left[{ }^{14} \mathrm{C}\right]$-polyethylene glycol (New England Nuclear, Boston, MA, USA) was added to the solution as a non-absorbable volume marker. The solution was perfused into a $20 \mathrm{~cm}$ long middle jejunal segment at a rate of $19 \mathrm{ml} / \mathrm{h}$. After an equilibration period of 30 minutes to achieve steady state conditions, the perfusate was collected for three consecutive 10 minute periods. At the end of each experiment, the perfused intestinal segment was removed and the mucosa was scraped and weighed. Galactose in the perfusate was estimated by the method of Batt and Peters. ${ }^{19}$ Glycine and gly-gly in the perfusate were determined by amino acid analyser as described previously. ${ }^{18}$ The absorption rate was expressed as $\mu \mathrm{mol}$ of substrate absorbed per minute per $\mathrm{g}$ mucosa of intestine.

\section{GLYCOPROTEIN PATTERN OF BRUSH BORDER} MEMBRANE BY SODIUM DODECYL SULPHATE POLYACRYLAMIDE GEL ELECTROPHORESIS AND AUTORADIOGRAPHY

Glycoprotein pattern of intestinal brush border membrane was compared in control and total parenteral nutrition rats using metabolic labelling technique with $\left[{ }^{3} \mathrm{H}\right]$-glucosamine and $\left[{ }^{3} \mathrm{H}\right]-$ fucose. $\mathrm{D}-\left[6-{ }^{3} \mathrm{H}\right]$-glucosamine hydrochloride (specific activity: $20-30 \mathrm{Ci} / \mathrm{mmol}$ ) and L- $\left[6-{ }^{3} \mathrm{H}\right]-$ fucose (specific activity: $10-15 \mathrm{Ci} / \mathrm{mmol}$ ) were obtained from New England Nuclear (Boston, MA, USA). Five hundred microcuries of isotope was instilled intraluminally into a ligated $20 \mathrm{~cm}$ segment of jejunum by injection with a 26 gauge needle. The abdominal cavity was closed, and the animals were allowed to recover. These rats were killed four hours after injection of the isotope, and jejunal segments were removed and flushed thoroughly with ice cold saline. Mucosal scrapings were prepared and homogenised in $40 \mathrm{ml} 2$
$\mathrm{mM}$ Tris-HCl-50 mM mannitol buffer, $\mathrm{pH} 7 \cdot 1$. Brush border membranes were subsequently isolated and subjected to sodium dodecyl sulphate polyacrylamide gel electrophoresis as described previously. ${ }^{20}$ Membranes were first solubilised by heating in $2 \%$-sodium dodecyl sulphate with 5\%-2-mercaptoethanol for five minutes at $100^{\circ} \mathrm{C}$ and then applied to the $7 \%$ gels. Gels containing $\left[{ }^{3} \mathrm{H}\right]$-labelled proteins were immersed in an autofluor solution for two hours, dried, and exposed to radiograph film (Kodak X-omat R Film).

DETERMINATION OF MOLECULAR WEIGHT OF SUCRASE ISOMALTASE IN BRUSH BORDER MEMBRANE

Two hundred microcuries of $\left[{ }^{35} S\right]$-methionine (specific activity: $84 \mathrm{Ci} / \mathrm{mmol}$ ) obtained from New England Nuclear (Boston, MA, USA) was injected into a ligated jejunal segment as described above. Four hours after the injection, the homogenate was made from mucosa of jejunal segment and brush border membrane was isolated. Brush border membranes containing $1 \times 10^{6} \mathrm{cpm}$ of trichloroacetic acid-insoluble $\left.{ }^{35} \mathrm{~S}\right]-$ methionine were solubilised with $1 \%$ Triton X-100 and immunoprecipitation was performed with rabbit antirat intestinal sucrose isomaltase (provided from Dr T Goda) ${ }^{21}$ as described by Gum et al. ${ }^{22}$ The immunoprecipitate was washed and subjected to sodium dodecyl sulphate polyacrylamide gel electrophoresis.

DETECTION OF SPECIFIC GLUCOSE TRANSPORTER Specific glucose transporter of intestinal brush border was detected by sodium dodecyl sulphate gel of fluorescein isothiocyanate labelled vesicles according to the method of Peerce and Wright. ${ }^{23}$ Briefly, vesicles $(250 \mu \mathrm{g})$ from control and total parenteral nutrition treated rat jejunum were treated with $2 \mathrm{mM}$ phenyl isothiocyanate (Sigma) in the presence of $10 \mathrm{mM}$ glucose and $100 \mathrm{mM}$ $\mathrm{NaCl}$ in $50 \mathrm{mM}$ Tris- $\mathrm{HCl} \mathrm{pH} 9.2$ and $2 \mathrm{mM}$ EDTA for 30 minutes at $22^{\circ} \mathrm{C}$. Vesicles were then treated with $50 \mu \mathrm{M}$ fluorescein isothiocyanate (Sigma) in the absence of $10 \mathrm{mM}$ glucose in the dark at $22^{\circ} \mathrm{C}$ for 15 minutes. Vesicles were suspended in $10 \mathrm{mM}$ Tris $\mathrm{HCl} \mathrm{pH} 6.8,1 \%$ sodium dodecyl sulphate and $\beta$-mercaptoethanol for 15 minutes at room temperature and centrifuged. Electrophoresis was performed on $7 \%$ slab gels according to the method of Laemmli. ${ }^{2+}$

TABLE I Mucosal weight, brush border membrane protein and brush border membrane enzyme activities of small intestine in rats with total parenteral nutrition

\begin{tabular}{|c|c|c|c|c|c|c|}
\hline & \multicolumn{2}{|c|}{ Proximal segment } & \multicolumn{2}{|c|}{ Middle segment } & \multicolumn{2}{|l|}{ Distal segment } \\
\hline & Control & $T P N$ & Control & $T P N$ & Control & $T P N$ \\
\hline $\begin{array}{l}\text { Intestinal mucosal weight } \\
(\mathrm{mg} / \mathrm{cm} \text { intestine })\end{array}$ & $63 \cdot 1(6 \cdot 2)$ & $23 \cdot 3(3 \cdot 3) \ddagger$ & $52 \cdot 5(6 \cdot 0)$ & $22 \cdot 4(3 \cdot 1) \ddagger$ & $44 \cdot 2(3 \cdot 1)$ & $21 \cdot 2(2 \cdot 2) \ddagger$ \\
\hline $\begin{array}{l}\text { Brush border membrane } \\
\text { protein (mg/g mucosa) }\end{array}$ & $1.82(0.22)$ & $1.74(0 \cdot 18), \mathrm{ns}$ & $1.59(0.28)$ & $1.47(0.34), \mathrm{ns}$ & $1.07(0.30)$ & $1.07(0.32), \mathrm{ns}$ \\
\hline \multicolumn{7}{|l|}{$\begin{array}{l}\text { Enzyme activities ( } \mu \mathrm{mol} / \\
\mathrm{min} / \mathrm{mg} \text { protein) }\end{array}$} \\
\hline $\begin{array}{l}\text { Alkaline phosphatase } \\
\text { Sucrase-isomaltase } \\
\text { Maltase } \\
\text { Amino peptidase N }\end{array}$ & $\begin{array}{c}43 \cdot 2(7 \cdot 6) \\
1.66(0 \cdot 29) \\
12 \cdot 3(1 \cdot 9) \\
0.89(0 \cdot 26)\end{array}$ & $\begin{array}{l}18 \cdot 4(5 \cdot 2) \ddagger \\
1.02(0 \cdot 30) \dagger \\
8 \cdot 4(1 \cdot 8) \dagger \\
0.66(0 \cdot 28), \mathrm{ns}\end{array}$ & $\begin{array}{l}12.6(3.4) \\
1.50(0.20) \\
11.6(1 \cdot 7) \\
1.08(0.23)\end{array}$ & $\begin{array}{l}7.8(3.0)^{\star} \\
0.92(0.16) \ddagger \\
6.8(1.4) \ddagger \\
0.73(0.23)^{\star}\end{array}$ & $\begin{array}{l}3.0(1 \cdot 5) \\
0.82(0 \cdot 28) \\
6 \cdot 1(2 \cdot 0) \\
0.70(0 \cdot 20)\end{array}$ & $\begin{array}{l}2 \cdot 8(1 \cdot 9), \mathrm{ns} \\
0.72(0 \cdot 38), \mathrm{ns} \\
5 \cdot 2(2 \cdot 2), \mathrm{ns} \\
0.57(0 \cdot 26), \mathrm{ns}\end{array}$ \\
\hline
\end{tabular}

Mean (SD) of seven experiments ${ }^{\star} \mathrm{p}<0.05,+\mathrm{p}<0.01, \neq \mathrm{p}<0.001$, as compared with control values. $\mathrm{ns}=$ not significant; TPN=total parenteral nutrition. 
TABLE II In vivo absorption of galactose, glycine and glycylglycine from jejunal perfuse loops in rats with total parenteral nutrition

\begin{tabular}{|c|c|c|c|}
\hline \multirow[b]{2}{*}{ Galactose } & \multicolumn{2}{|c|}{$\begin{array}{l}\text { Control ( } \mu \mathrm{mol} / \mathrm{min} / \mathrm{g} \\
\text { mucosa) }\end{array}$} & \multirow{2}{*}{$\begin{array}{l}\operatorname{TPN}(\mu \mathrm{mol} / \mathrm{min} / \mathrm{g} \\
\mathrm{mucosa})\end{array}$} \\
\hline & $\begin{array}{l}16 \mathrm{mM} \\
32 \mathrm{mM}\end{array}$ & $\begin{array}{l}1.85(0.17) \\
3.87(0.26)\end{array}$ & \\
\hline Glycine & $20 \mathrm{mM}$ & $1.98(0.30)$ & $1.92(0.36)$, ns \\
\hline Glycylglycine & $\begin{array}{l}50 \mathrm{mM} \\
10 \mathrm{mM}\end{array}$ & $\begin{array}{l}5.16(0.46) \\
0.77(0.06)\end{array}$ & $\begin{array}{l}4 \cdot 77(0.56), \mathrm{ns} \\
0 \cdot 80(0.09), \mathrm{ns}\end{array}$ \\
\hline
\end{tabular}

Mean (SD) of six experiments ${ }^{\star} \mathrm{p}<0.01$ as compared with control values. $\mathrm{ns}=$ not significant; $\mathrm{TPN}=$ total parenteral nutrition.

After electrophoresis, fluorescein isothiocyanate in the slices was determined by spectrofluorometer (JASCO, FP-550, Tokyo).

STATISTICAL ANALYSIS

Data were analysed for significance of difference using Student's $t$ test.

\section{Results}

\section{ANIMAL CHARACTERISTICS}

During total parenteral nutrition treatment, there was no significant difference in the increase

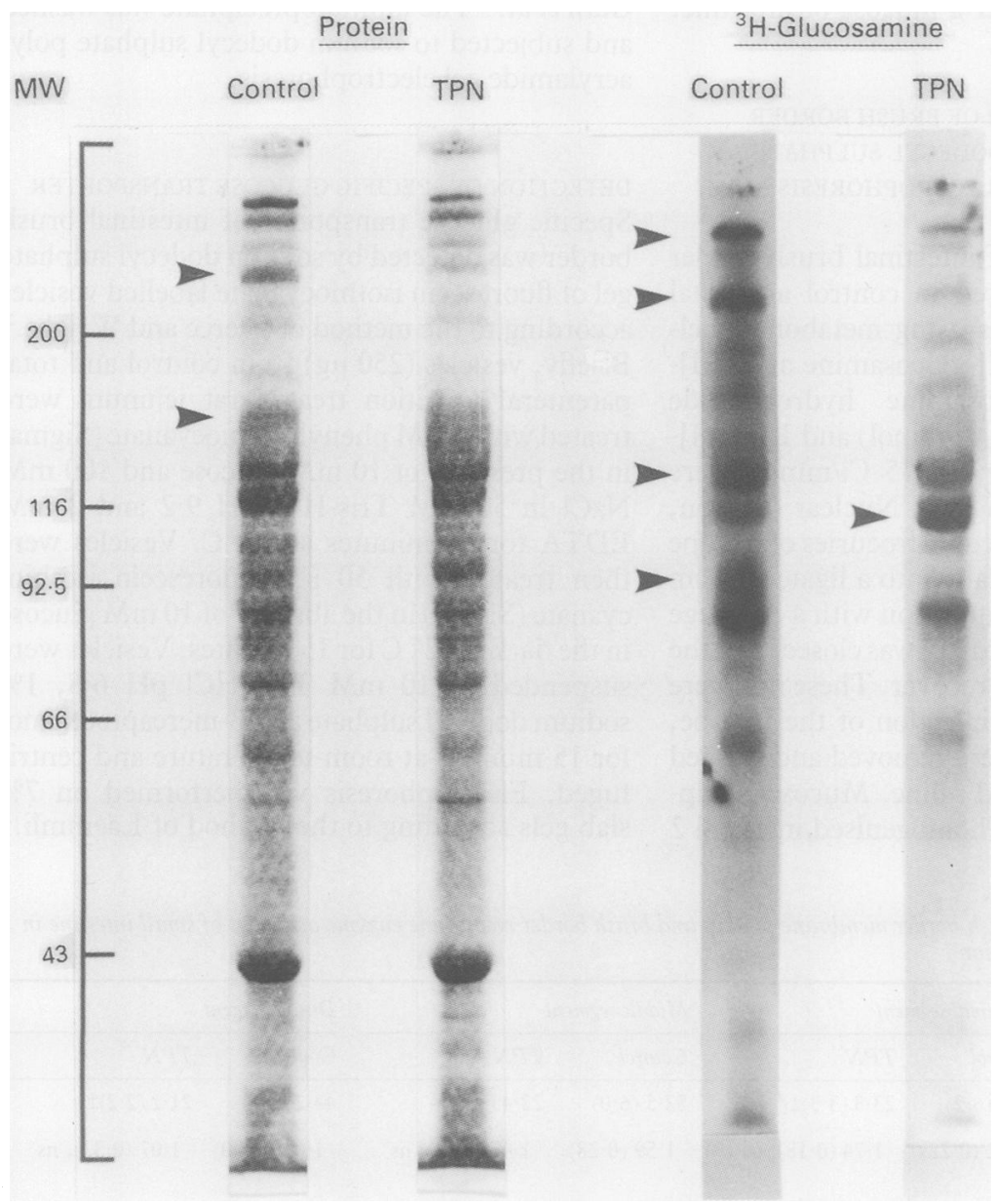

Figure 1: Effect of total parenteral nutrition (TPN) on the sodium dodecyl sulphate polyacrylamide gel electrophoresis (SDS-PAGE) profiles of brush border membrane proteins and glycoproteins labelled in vivo with [ $\mathrm{H}]$-glucosamine. Left: protein bands stained with Coomassie blue; right: radioautography of brush border membrane glycoproteins labelled with $[\mathrm{H}]$-glucosamine. In all cases $50 \mu \mathrm{g}$ protein was applied to each lane. Arrow heads indicate increased or decreased staining of protein and [ $\mathrm{H}]$-glucosamine labelled glycoprotein bands. Experimental details are described in the text. of body weight between control and total parenteral nutrition treated rats and after 14 days, the weight gain being $49(5) \mathrm{g}$ in controls and $45(6) \mathrm{g}$ in total parenteral nutrition treated rats. There were also no significant differences in serum total protein, albumin, cholesterol, blood sugar, urea nitrogen, and haemoglobin concentrations between two groups, indicating that systemic metabolic changes did not occur throughout total parenteral nutrition period as judged by these parameters.

BRUSH BORDER MEMBRANE PROTEIN AND ENZYME ACTIVITIES

As shown in Table I, there was marked decrease in intestinal mucosal weight throughout the small intestine in total parenteral nutrition rats. When brush border membrane was purified and compared as mg brush border membrane per gram intestinal mucosal protein basis, however, there was no significant difference between two groups in any segment of the intestine, revealing that there was no selective loss of brush border membrane protein compared with other mucosal proteins after total parenteral nutrition treatment. Intestinal brush border enzyme activities are also shown in Table I. In control rats, all enzyme activities of brush border membranes isolated from different regions showed considerable difference along the length of the small intestine. The proximal segment contained three, four times higher activity of alkaline phosphatase than the middle segment and there were very low specific activities in the distal segment. In the case of disaccharidases and aminopeptidase $\mathrm{N}$, these enzymes had a maximum peak in the midintestine, decreasing to approximately half maximum in the distal end. Total parenteral nutrition treatment appeared to decrease specific activities of all these enzymes mainly in the proximal and middle segment of the intestine. Distal segment was not significantly affected by total parenteral nutrition treatment, resulting in the attenuation of proximal distal gradient of enzyme activities in these brush border enzymes.

INTESTINAL ABSORPTION STUDIES

Table II compared the absorptive function of galactose, glycine, and glycylglycine in vivo by using steady state perfusion technique in control and total parenteral nutrition rat jejunum. When galactose absorption from jejunal loops was compared, significant inhibition of galactose uptake from the mucosa was observed in total parenteral nutrition rats compared with controls in both 16 and 32 millimolar concentrations.

On the other hand, neutral amino acid, glycine and dipeptide, glycylglycine are supposed to be transported by different carrier systems from that of glucose-galactose. When glycine was perfused into the jejunal loops, there was no significant inhibition of glycine transport from intestine after total parenteral nutrition treatment. Our perfusion study also revealed that there was no difference in glycylglycine absorption between total parenteral nutrition and control rat small intestines as shown in Table II. 


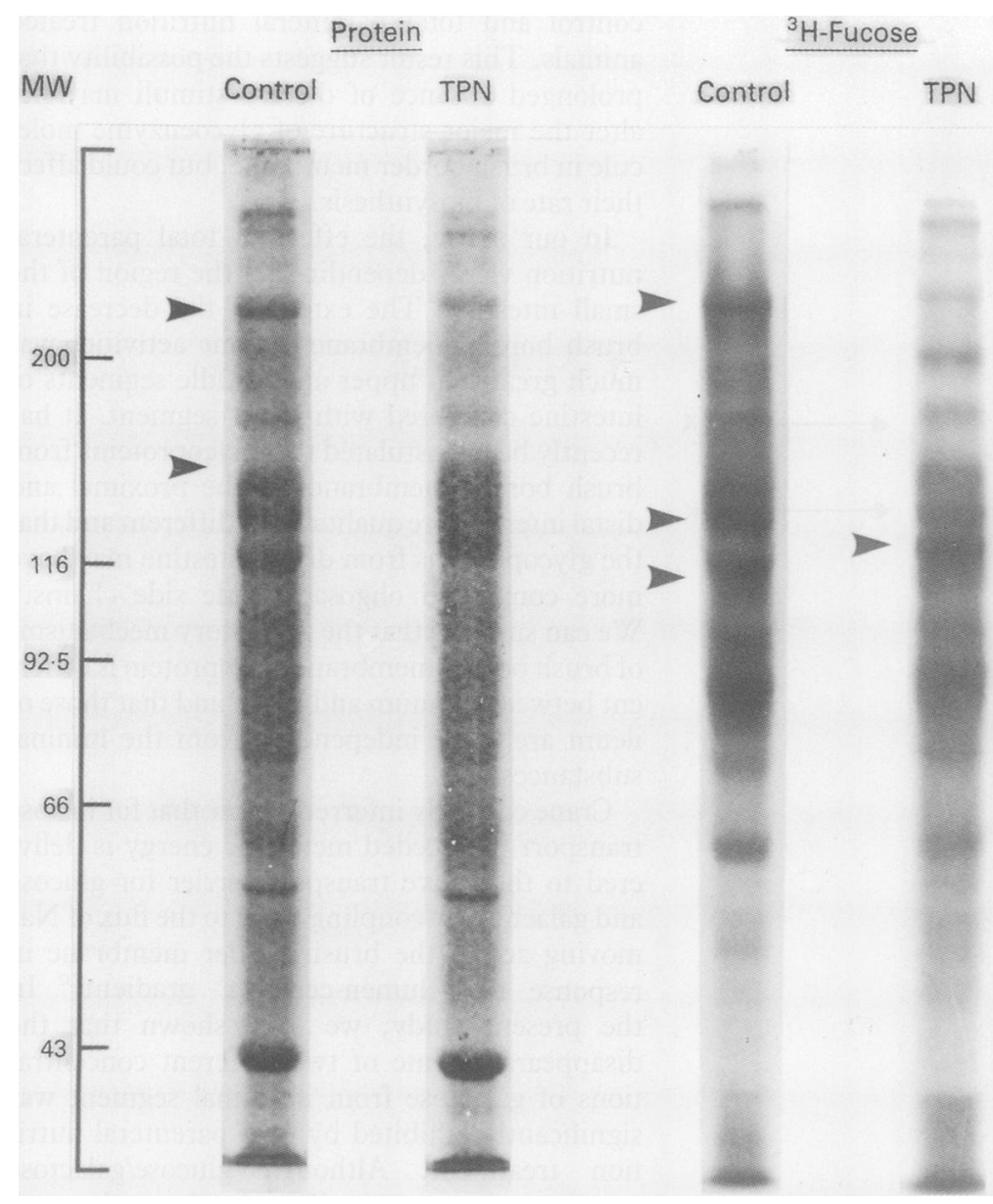

Figure 2: Effect of total parenteral nutrition on the sodium dodecyl sulphate polyacrylamide gel electrophoresis profiles of brush border membrane proteins and glycoproteins labelled in vivo with $\left[{ }^{3} \mathrm{H}\right]$-fucose. Left: protein bands stained with Coomassie blue; right: radioautography of brush border membrane glycoproteins labelled with [ $\mathrm{H}$ ]-fucose. In all cases $50 \mu \mathrm{g}$ protein was applied to each lane. Arrow heads indicate increased or decreased staining of protein and $\left.{ }^{3} \mathrm{H}\right]$-fucose labelled glycoprotein bands. Experimental details are described in the text. parenteral nutrition treatment and especially high molecular weight glycoprotein bands over $120 \mathrm{kDa}$ were mainly suppressed in total parenteral nutrition rats. Namely, glucosamine incorporation into $250,210,120$ and $85 \mathrm{kDa}$ glycoprotein were remarkably decreased in total parenteral nutrition rats, in contrast with the increase of glycoprotein incorporation into 110 $\mathrm{kDa}$ glycoprotein. Fucosylated glycoprotein pattern in control and total parenteral nutrition rats is shown in Figure 2. Similar to the $\left[{ }^{3} \mathrm{H}\right]-$ glucosamine incorporation, there was selective decrease in several bands, mainly glycoproteins of molecular weight over $120 \mathrm{kDa}$ after total parenteral nutrition treatment. In total parenteral nutrition rats, the fucosylated glycoprotein synthesis of 220,120,100 kDa was significantly decreased, whereas $110 \mathrm{kDa}$ glycoprotein was rather increased. From these observations, there is possibility that by the total parenteral nutrition treatment, mainly biosynthesis of high molecular weight glycoproteins are suppressed in the brush border membrane of jejunal mucosa.

MOLECULAR WEIGHT OF SUCRASE ISOMALTASE Sucrase isomaltase isolated from jejunum of total parenteral nutrition treated rat contained 120 $\mathrm{kDa}$ of sucrase subunit and $140 \mathrm{kDa}$ of isomaltase subunit as judged by sodium dodecyl sulphate polyacrylamide gel electrophoresis in denatured condition. These molecular weights of sucrase and isomaltase were identical to those of control rat (Fig 3).

\section{MOLECULAR WEIGHT OF SPECIFIC GLUCOSE} TRANSPORTER

Molecular weight of specific sodium glucose cotransporter of intestinal brush border membrane was analysed by fluorescein isothiocyanate using sodium dodecyl sulphate polyacrylamide gel electrophoresis (Fig 4). The molecular weight of this transporter was $80 \mathrm{kDa}$, and this molecular weight was not altered after total parenteral nutrition treatment, suggesting that so far as each glucose transporter is concerned, no significant changes in molecular form of transporter had occurred with total parenteral nutrition treatment in spite of the decreased glucose absorption.

by the autoradiography of sodium dodecyl sulphate gel electrophoresis. As shown in Figures 1 and 2, a comparison of control and total parenteral nutrition treated brush border membrane protein profiles on sodium dodecyl sulphate polyacrylamide gels revealed distinct differences. The control jejunal brush border membranes had prominent bands of 140 and 220 $\mathrm{kDa}$, while the total parenteral nutrition treated jejunum showed their decrease. Incorporation of labelled glucosamine and fucose into the brush border membrane was decreased in total parenteral nutrition rats and their total counts incorporated into glycoproteins were about two-thirds of those of control rats as expressed by counts/mg membrane protein. As shown in Figure 1, glycoproteins labelled by $\left[{ }^{3} \mathrm{H}\right]$-glucosamine showed intense labelling in the region from $80-250 \mathrm{kDa}$ in the control rat jejunum. There were significant changes in their incorporation pattern after total

\section{Discussion}

The brush border membrane of intestinal mucosal cells contains various kinds of glycoconjugates and their carbohydrate moieties have been shown to be involved in many important biological functions. ${ }^{25-28} \mathrm{~A}$ variety of membrane associated hydrolytic enzymes and transporter proteins play an especially important role in the absorptive process and active transport of dietary nutrients. These enzymes are known to be glycosylated to varying degrees and their process of biosynthesis and expression at the cell surface has recently been investigated..$^{29}{ }^{30}$ Their regulation has still been poorly defined, however. This study was designed to elucidate changes of brush border function and glycoprotein composition in response to total parenteral nutrition. 


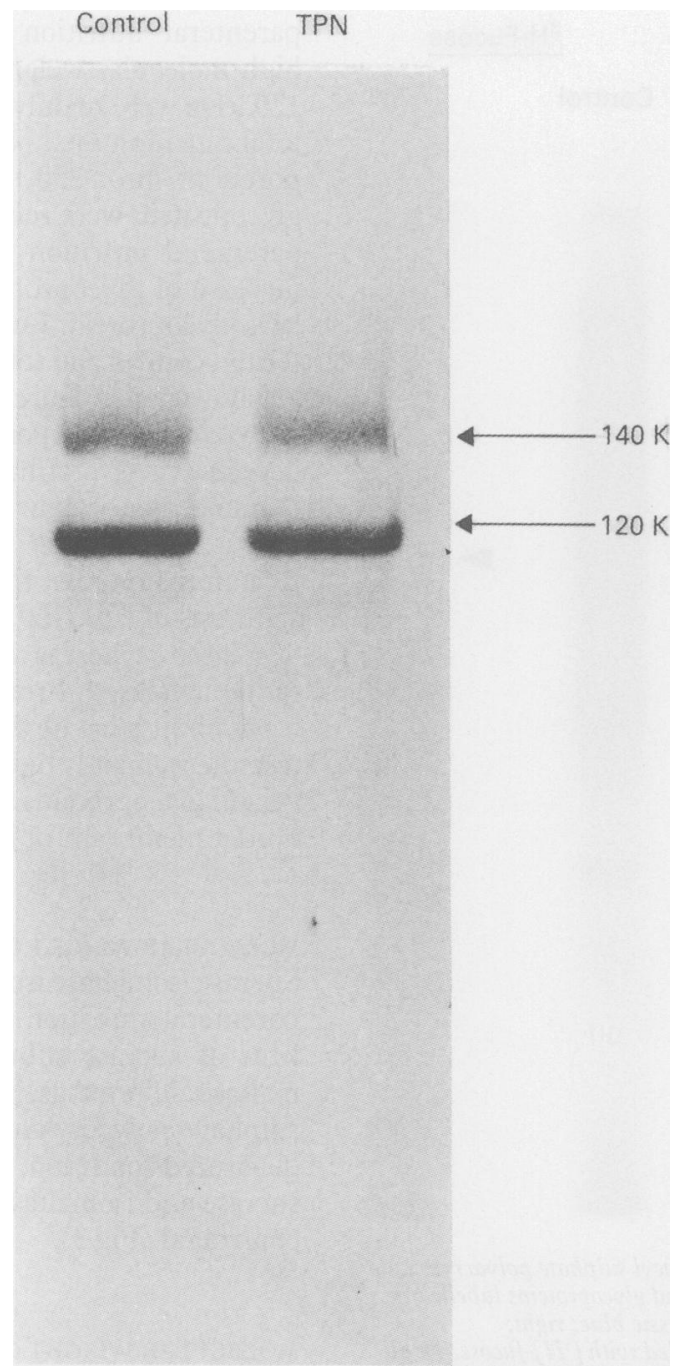

Figure 3: Immunopurified sucrase isomaltase (SI) from intestine of total parenteral nutrition $(T P N)$ and control rat. Sucrase isomaltase molecules were determined by rabbit antirat intestinal sucrase isomaltase from ${ }^{35} S 1$-methioninelabelled brush border membrane as described in the text. Molecular weight of $S$ and I was approximately $120 \mathrm{kDa}$ and $140 \mathrm{kDa}$ respectively. No difference in molecular weight of sucrase isomaltase between total parenteral nutrition treated and control rat was observed.

In total parenteral nutrition treatment, significant changes occurred in the glycoprotein pattern of brush border membrane, especially those of higher molecular weight over $120 \mathrm{kDa}$ in our study of radiolabelled sugar incorporation. Decrease in these glycoproteins suggests the possibility that glycoproteins in brush border membrane were continuously stimulated by the luminal substances which have direct contact with mucosa. As four hours after the administration of radiolabelled sugar, these glycoproteins are supposed to be just processed to the brush border membrane at that time,,$^{14}$ these changes by total parenteral nutrition may reflect the alteration of their de novo biosynthesis rather than the changes in their degradation process. This considerable heterogeneity in the changes in biosynthesis of brush border membrane glycoproteins may correlate their different response against dietary stimuli. When we examined sucrase isomaltase as a brush border membrane enzyme, however, there was no difference in the molecular weight of sucrase isomaltase between control and total parenteral nutrition treated animals. This result suggests the possibility that prolonged absence of dietary stimuli may not alter the major structure of glycoenzyme molecule in brush border membrane, but could affect their rate of biosynthesis.

In our study, the effect of total parenteral nutrition varies depending on the region of the small intestine. The extent of the decrease in brush border membrane enzyme activities was much greater in upper and middle segments of intestine compared with lower segment. It has recently been postulated that glycoproteins from brush border membranes of the proximal and distal intestine are qualitatively different and that the glycoproteins from distal intestine may have more completed oligosaccharide side chains. ${ }^{31}$ We can suppose that the regulatory mechanisms of brush border membrane glycoprotein is different between jejunum and ileum and that those of ileum are more independent from the luminal substances.

Crane correctly inferred earlier that for hexose transport the needed metabolic energy is delivered to the active transport carrier for glucose and galactose by coupling them to the flux of $\mathrm{Na}^{+}$ moving across the brush border membrane in response to a lumen-cell $\mathrm{Na}^{+}$gradient. ${ }^{32}$ In the present study, we have shown that the disappearance rate of two different concentrations of galactose from intestinal segment was significantly inhibited by total parenteral nutrition treatment. Although glucose/galactose transportation was significantly altered by total parenteral nutrition treatment, selective photoaffinity labelling for transporter properties showed that there were no significant changes in their molecular weight. Our results were in agreement with the observation of Kotler $e t a l^{7}$ who indicated that luminal nutrients maintain carrier mediated glucose transport after direct contact with the mucosa and that nutrient effect appears to involve an increased number of glucose carriers. On the other hand, glycine and glycylglycine absorption was not altered by the total parenteral nutrition treatment. As single or two substrate concentrations were used in these perfusion studies, it is difficult to interpret the characteristics of absorption such as carrier number or affinity. It is now known that there are multiple transporters for amino acids with overlapping specificity. At least four different $\mathrm{Na}^{+}$ dependent transport systems for neutral amino acids have been described for brush border membrane of the small intestine. ${ }^{33}$ Moreover, the transport systems for peptides differ from those for amino acids, but the number of these systems has not been clarified. ${ }^{34}$ Hoshi et al showed the relative importance of intact dipeptide transport in protein assimilation and suggested that glycylL-leucine uptake by guinea pig small intestine is actively transported through $\mathrm{H}^{+}$-ion dependent carrier system..$^{35}$ The exact reason why total parenteral nutrition did not affect glycine and glycylglycine absorption was not known. It may be justified to say, however, that the multiplicity of systems seems to work as a protective mechanism to ensure the adequate uptake of peptides. There might be complex interrelationships existing between the presence of luminal nutrients 


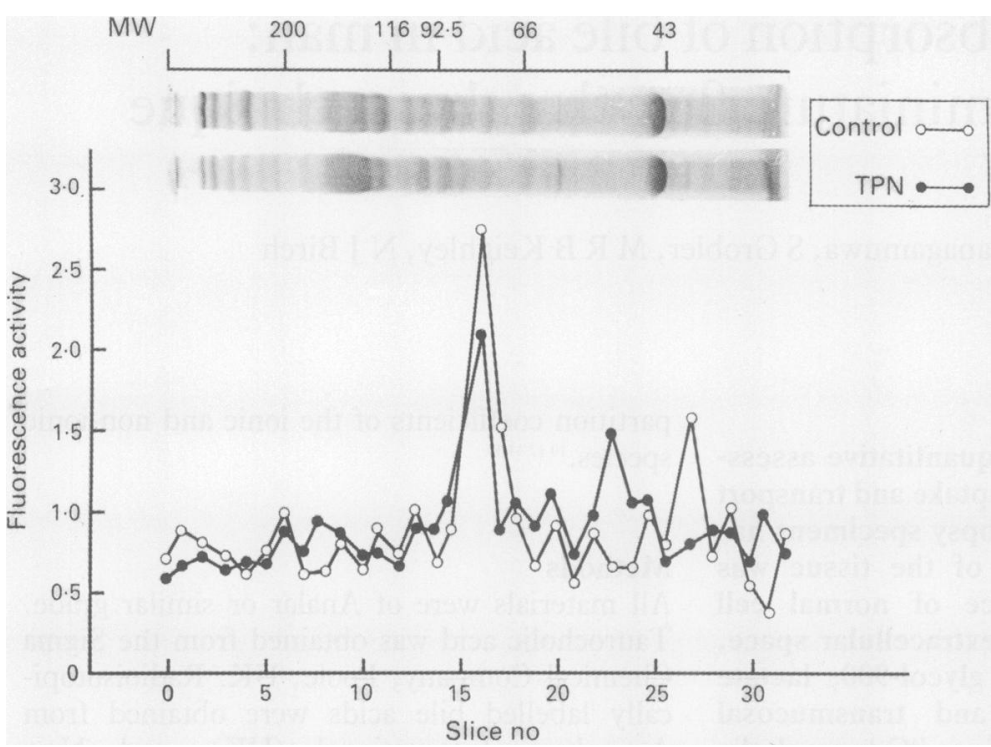

Figure 4: Effect of total parenteral nutrition (TPN) on the molecular weight of specific glucose transporter of intestinal brush border in the sodium dodecyl sulphate gel of fluorescein isothiocyanate labelled vesicles. After electrophoresis, one track was stained with Coomassie blue $(50 \mu \mathrm{g}$ protein) and a parallel track processed for fluorescein isothiocyanate fluorescence as described in the text. Gels were sliced into pieces $(3 \mathrm{~mm})$ and the fluorescence activity was determined in each slice. Key: $(\mathrm{O}-\mathrm{O})$ controls; and $(\mathbf{O})$ total parenteral nutrition rats.

and the regulation of nutrient absorption. As we have shown that there are indeed considerable heterogeneities of total parenteral nutrition effect among different glycoenzymes and transporter proteins, there should be many different kinds of regulatory signals such as transported substrate itself and neurohumoral substances participating in the biosynthesis of glycoproteins in the brush border membrane of rat small intestine. It remains to be elucidated which of the regulatory signals is important in the physiological condition.

This work is supported by the grant from Japanese Ministry of Education and by the grant from Keio University, School of Medicine. The authors thank Dr T Goda, School of Food and Nutritional Science, University of Shizuoka, Japan, for providing us antibody of sucrase isomaltase.

1 McManus PA, Isselbacher KJ. Effect of fasting versus feeding on the rat small intestine. Gastroenterology 1970; 59: 214-21.

2 Levine GM, Daren JJ, Steiger E, Zinno R. Role of oral intake in maintenance of gut mass and disaccharidase activity. in maintenance of gut mass and
Gastroenterology $1974 ; 67: 975-82$.

3 Castro GA, Copeland EM, Dudrick SJ, Johnson LR. Intestinal disaccharidase and peroxidase activities in parenterally nourished rats. F Nutr 1975; 105: 776-81.

4 Johnson LR, Copeland EM, Dudrick SJ, Lichtenberger LM, Castro GA. Structural and hormonal alterations in the gastrointestinal tract of parenterally fed rats. Gastroenterology 1975; 68: 1177-83.

5 Koga Y, Ikeda K, Inokuchi K, Watanabe H, Hashimoto N The digestive tract in total parenteral nutrition. Arch Surg 1975; 110: 742-4.

6 Madara JL, Trier JS. Functional morphology of the mucosa of the small intestine. In: Johnson LR, ed. Physiology of the gastrointestinal tract. 2nd ed. New York: Raven Press, 1987: 1209-50.

7 Kotler DP, Levine GM, Shian Y-F. Effects of nutrients, endogenous secretions, and fasting on in vitro glucose
uptake. Am $\mathcal{F}$ Physiol (Gastrointest Liver Physiol) 1980; 238: uptake. $A$.

8 Weser E, Vandeventer A, Tawil T. Non-hormonal regulation of intestinal adaptation. Scand $\mathcal{F}$ Gastroenterol 1982; 77 (suppl): 105-13.

9 Levine GM. Nonspecific adaptation of jejunal amino acid uptake in the rat. Gastroenterology 1986; 91: 49-55.
10 Hughes CA, Dowling RH. Speed of onset of adaptive mucosal hypoplasia and hypofunction in the intestine of parenterally fed rats. Clin Sci 1980; 59: 317-27.

11 Guedon C, Schmitz J, Lerebours E, Metayer J, Andran E, Hemet $\mathrm{J}$, et al. Decreased brush border hydrolase activities without gross morphologic changes in human intestinal mucosa after prolonged total parenteral nutrition of adults Gastroenterology 1986; 90: 373-8.

12 Steiger E, Vars HM, Dudrick SJ. A technique for long-term intravenous feeding in unrestrained rats. Arch Surg 1972; 104: $330-2$.

13 Kessler J, Acuto O, Storell C, Murer H, Müller M, Semenza $G$. A modified procedure for the rapid preparation of efficiently transporting vesicles from small intestinal brush border membranes. Their use in investigating some properties of D-glucose and choline transport systems. Biochim Biophys Acta 1978; 506: 136-54.

14 Miura S, Morita A, Erickson RH, Kim YS. Content and turnover of rat intestinal microvillus membrane aminopeptidase. Effect of methylprednisolone. Gastroenterology 1983 85: $1340-9$.

15 Fujita M, Ohta H, Kawai K, Matsui H, Nakao M. Differential isolation of microvillous and basolateral plasma membranes from intestinal mucosa: mutually exclusive distribution of digestive enzymes and ouabain-sensitive ATP ase. Biochim digestive enzymes and ouabain-se

16 Dahlqvist A. Assay of intestinal disaccharidases. An Biochem 1968; 27: 99-107.

17 Lowry OH, Rosebrough NJ, Farr AL, Randall RJ. Protein measurement with the Folin phenol reagent. $\mathcal{F}$ Biol Chem 1951; 193: 265-75.

18 Chung YC, Silk DBA, Kim YS. Intestinal transport of a tetrapeptide, L-leucylglycylglyclglycine, in rat small intestine in vivo. Cin Sci 1979; 57: 1-11.

19 Batt RM, Peters TJ. Absorption of galactose by the rat small intestine in vivo: proximal-distal kinetic gradients and a new method to express absorption per enterocyte Clin Sci Mol Med 1976; 50: 499-509.

20 Miura S, Erickson RH, Song I-S, Kim YS. In vivo effect of tunicamycin on the expression of rat small intestinal brush border membrane glycoproteins and glycoenzymes. Biochem Porder membrane glycoprotein

21 Goda T, Quaroni A, Koldovsky O. Characterization of degradation process of sucrase-isomaltase in rat jejunum with monoclonal-antibody-based enzyme-linked immunosorbent assay. Biochem f 1988; 250: 41-6.

22 Gum JP, Kam WK, Byrd JC, Hicks JW, Sleisenger MH, Kim YS. Effects of sodium butyrate on human colonic adenocarcinoma cells. Induction of placental-like alkaline phosphatase. F Biol Chem 1987; 262: 1092-7.

23 Peerce BE, Wright EM. Sodium-induced conformational changes in the glucose transporter of intestinal brush borders. F Biol Chem 1984; 259: 14105-12.

24 Laemmli UK. Cleavage of structural proteins during the assembly of the head of bacteriophage T4. Nature 1970;227: assemb 680 .

25 Herscovics A, Quaroni A, Bugge B, Rirsch K. Partial characterization of the carbohydrate units of rat intestinal sucraseisomaltase. Biochem $\mathcal{F} 1981 ; 197$ : 511-4.

26 Kim YS, Brophy EJ. Rat intestinal brush border membrane peptidase. 1. Solubilization, purification and physiochemical properties of two different forms of the enzyme. $7 \mathrm{Bio}$ Chem 1976; 251: 3199-205.

27 Jacobs S, Hazum E, Cuatrecasas P. Digestion of insulin receptors with proteolytic \& glycosidic enzymes - effects on purified \& membrane associated receptor subunits. Biochem Biophys Res Commun 1980; 94: 1066-73.

28 Morita A, Tsao D, Kim YS. Identification of cholera toxin binding glycoproteins in rat intestinal microvillus binding glycoproteins in rat intestinal
membranes. F Biol Chem 1980; 255: 2549-53.

29 Hauri H-P, Quaroni A, Isselbacher KJ. Biogenesis of intestinal plasma membrane: posttranslational route and cleavage of sucrase-isomaltase. Proc Natl Acad Sci USA 1978; 76: 5183 6.

30 Ahnen DJ, Mircheff AK, Santiago NA, Yoshioka C, Gray GM. Intestinal surface aminooligopeptidase. Distinct molecular forms during assembly of intracellular membranes in vivo. F Biol Chem 1983; 258: 5955-60.

31 Morita A, Miura S, Erickson RH, Sleisenger MH, Kim YS Comparison of brush border membrane glycoprotein and . Biochim Biophys Acta 1986; 883: 506-16.

32 Crane RK. Hypothesis of mechanism of intestinal active transport of sugars. Fed Proc 1962; 21: 891-5.

33 Hopfer U. Membrane transport mechanisms for hexoses and amino acid in the small intestine. In: Johnson LR, ed. Physiology of gastrointestinal tract. 2nd ed. New York: Raven Physiology of gastrointestina
Press, 1987: 1499-525.

34 Alpers DH. Digestion and absorption of carbohydrate and proteins. In: Johnson LR, ed. Physiologv of the gastrointestinal tract. 2nd ed. New York: Raven Press, 1987: 1469-97.

35 Himukai M, Hoshi T. Mechanisms of glycyl-L-leucine uptake by guinea pig small intestine: relative importance of intac peptide transport. F Physiol (London) 1980; 302: 155-69. 